Leszek Waga*

ORCID: 0000-0002-2159-5950

Opole, Poland

\title{
Integration of Pedagogical Knowledge in the Light of Questions about the Empirical Foundations of General Pedagogy and Understanding of the Concept of Generality
}

\section{Integracja wiedzy pedagogicznej w świetle pytań o empiryczne podstawy pedagogiki ogólnej i o rozumienie pojęcia ogólności}

Summary: The main purpose of the article is to show that the studies undertaken by pedagogues, regarding both the experimental foundations of pedagogy and generality, have some common points and that an in-depth reflection on those issues highlights the postulate to treat pedagogical knowledge in an integral manner. The first part presents the relationship between the issue of the empirical foundations of pedagogy and the problems of integrity of pedagogical knowledge; the second part the relationship between the concept of generality and the problems of integrity, and the concluding part presents a proposed understanding of general pedagogy as integral pedagogy in which the approach towards both empirical sources of pedagogical

* Leszek Waga, Ph.D., Assistant Professor in the Chair of Psychology and Pedagogy of Family at the Institute of Family Studies at the Faculty of Theology of the University of Opole (Poland). Address: Wydział Teologiczny UO, ul. Drzymały 1a, 45-342 Opole, e-mail: lwaga@uni.opole.pl. 
knowledge and the generality category are the integrating element. The analyses carried out made it possible to consider general pedagogy as a specific type of reflection on education, or as a mental structure, the tasks of which include integration of the entire pedagogical knowledge. Fulfilment of that task may valourise general pedagogues' scientific activity as recognition of the fact that in the experienced research reality there are incomprehensible elements that demand generality (celebration) build the pedagogue's authority.

Keywords: experience; generality; pedagogical knowledge; general pedagogy; integral pedagogy.

Streszczenie: Głównym celem artykuły jest pokazanie, że podejmowane przez pedagogów badania zarówno nad empirycznymi podstawami pedagogiki, jak i nad ogólnościa, posiadają punkty styczne oraz, że pogłębiona refleksja nad tymi zagadnieniami ukierunkowuje na postulat integralnego traktowania wiedzy pedagogicznej. W pierwszej części została przedstawiona relacja między kwestią empirycznych podstaw pedagogiki a problematyką integralności wiedzy pedagogicznej, w drugiej - między pojęciem ogólności a problematyką tejże integralności, natomiast w zakończeniu zaprezentowano propozycję rozumienia pedagogiki ogólnej jako pedagogiki integralnej, w której elementem integrującym jest sposób podejścia zarówno do empirycznych źródeł wiedzy pedagogicznej, jak i do kategorii ogólności. Przeprowadzone analizy pozwoliły traktować pedagogikę ogólną jako specyficzny typ myślenia o wychowaniu, bądź jako myślowa konstrukcje, do której zadań należy integracja całej wiedzy pedagogicznej. Spełnienie tego zadania może waloryzować działalność naukową pedagogów ogólnych, gdyż uznanie faktu, że w doświadczanej rzeczywistości badawczej istnieją elementy niezrozumiałe, domagające się ogólności (świętowania), buduje autorytet pedagoga.

Słowa kluczowe: doświadczenie; ogólność; wiedza pedagogiczna; pedagogika ogólna; pedagogika integralna.

Generality is one of the key concepts constituting the subject matter of contemporary scientific analyses in pedagogy, frequently accompanied by the question about the methodological status of empirical sources of pedagogy. The main purpose of this article is to show that the studies undertaken by pedagogues in the area of the empirical foundations of pedagogy, and of generality, have some points in common, and that an in-depth reflection on those 
issues refers to the postulate to integrally treat pedagogical knowledge understood as "[knowledge] related to the investigation of pedagogy, obtained in the process of pedagogical research, developed in the field of pedagogy"1. Firstly, the article will present the relationship between the issue of the empirical foundations of pedagogy and the problems of integrity of pedagogical knowledge, then - between the concept of generality and the problems of that integrity, followed by a presentation of a proposed understanding of general pedagogy as integral pedagogy in which the approach towards both the empirical sources of pedagogical knowledge and the generality category is the integrating element.

\section{Empirical foundations of pedagogy vs. integration of pedagogical knowledge}

The problem of the empirical foundations of pedagogy may be studied from various angles as the problem of empiricism itself is most diversified. Amongst its directions, genetic, theoretical and methodological empiricism are distinguished. The first of them is related to the dispute with nativism, the second one - with rationalism, and the third (similar to the second one) with apriorism ${ }^{2}$. Theoretical and methodological typologies of the concept ${ }^{3}$ indicate a vast range of issues related to the experience category. Pedagogy as a real (inductive) science allows for those typologies in the studies covering its subject matter. As a scientific discipline, it may also offer its own, characteristic typologies of the experience category, referring to, for example, all the elements of the educational relationship. If so, experience may be

1 Stanisław Palka, „Wiedza w pedagogice i wiedza pedagogiczna”, in: Metodologiczne problemy tworzenia wiedzy w pedagogice. Oblicza akademickiej praktyki, eds. Jacek Piekarski, Danuta Urbaniak-Zając, Krzysztof J. Szmidt (Kraków: PTP, Oficyna Wydawnicza „Impuls”, 2010), 18.

${ }^{2}$ Wojciech Sokołowski, „Empiryzm”, in: Powszechna Encyklopedia Filozofii, vol. 3, ed. Andrzej Maryniarczyk (Lublin: Polskie Towarzystwo Tomasza z Akwinu, 2002), 142-147; cf. Antoni B. Stępień, Wstęp do filozofii (Lublin: Towarzystwo Naukowe Katolickiego Uniwersytetu Lubelskiego, 2001), 130-133; Jan Woleński, Epistemologia. Poznanie. Prawda. Wiedza. Realizm (Warszawa: Wydawnictwo Naukowe PWN, 2007), 417-419.

3 Antoni B. Stępień, „Rodzaje bezpośredniego poznania”, Roczniki Filozoficzne 1 (1971): 106; Antoni B. Stępień, „Rola doświadczenia w punkcie wyjścia metafizyki”, Zeszyty Naukowe KUL 4 (1974): 34-35; Antoni B. Stępień, Wstęp, 119-120; Zygmunt Hajduk, Ogólna metodologia nauk (Lublin: Wydawnictwo KUL, 2005), 118-120. 
analysed in the context of its subjects (student and educator) and its subject matter (i.e. the educational situation) . $^{4}$

Allowing for the need to link the empirical foundations of pedagogy with the problems of integration of pedagogical knowledge, it is worth remembering the vertical arrangement of pedagogical sub-disciplines proposed by Stefan Kunowski ${ }^{5}$ and slightly modified by Marian Nowak ${ }^{6}$. The vertical structure refers to the methodological typologies of experience as it notes its different types as different sources of knowledge (observation, experiment). It is also related to the problems of epistemology as it relates to the problem of the relationship between experience and theory, and to the status of empirical data in the development of scientific knowledge, in turn, it also refers to the historical process of pedagogy establishment as a science.

It distinguishes: $1^{\circ}$ practical or empirical pedagogy; $2^{\circ}$ descriptive or experimental pedagogy; $3^{\circ}$ normative pedagogy; $4^{\circ}$ theoretical, i.e. general pedagogy ${ }^{7}$.

The task of practical (empirical) pedagogy is to observe, collect and study the whole educational experience of parents, teachers, educators and other educating entities, and to work on the didactic and methodological experience gained in the course of the teaching and learning process. Consequently, it is pedagogy relating to practice and specific experience.

The task of descriptive (experimental) pedagogy is to generalise experience and to carry out experimental research in the field of laws governing the phenomena occurring in the educational process. Thus, while describing the circumstances and manifestations of cultural phenomena, we study certain phenomena in their biological, psychological, sociological and cultural aspects.

${ }^{4}$ Leszek Waga, Rola doświadczenia w tworzeniu wiedzy pedagogicznej (Lublin: typescript Katolicki Uniwersytet Lubelski Jana Pawła II, 2016), 155-306. The reflections contained in this article, discussing the experience category, are a summary of the analyses carried out in the study cited herein.

5 Stefan Kunowski, Podstawy wspótczesnej pedagogiki (Warszawa: Wydawnictwo Salezjańskie, 2000), 38.

${ }^{6}$ Marian Nowak, Podstawy pedagogiki otwartej. Ujęcie dynamiczne w inspiracji chrześcijańskiej (Lublin: RW KUL, 2000), 96-97; Marian Nowak, „Od tradycji pedagogiki ogólnej ku nowym wyzwaniom dla badań nad podstawami edukacji”, in: Pedagogika ogólna. Tradycjateraźniejszość - nowe wyzwania (materiaty pokonferencyjne), ed. Teresa Hejnicka-Bezwińska (Bydgoszcz: Wydawnictwo Uczelniane WSP w Bydgoszczy, 1995), 109.

${ }^{7}$ Cf. Teresa Hejnicka-Bezwińska, W poszukiwaniu tożsamości pedagogiki. Świadomość teoretyczno-metodologiczna wspótczesnej pedagogiki polskiej (geneza i stan) (Bydgoszcz: Wydawnictwo Uczelniane WSP w Bydgoszczy, 1989), 238-239. 
The task of normative pedagogy, based on the philosophy of a human, axiology and theory of culture, is to analyse the human nature, its creations and worldviews in order to describe the values, goals, ideals and norms present in the process of education in the light of the former.

On the other hand, the task of theoretical pedagogy (general pedagogy, systems of education, philosophy of education) is to build a general theory of the educational reality (a unified theory of comprehensive human development and its conditions). This pedagogy is based on empirical, experimental and normative material provided by the lower sub-disciplines of the vertical structure $^{8}$.

The structure shown enables us to notice the trend of transition from knowledge related to the experience of the educator and of the student, and from the knowledge gained through experience (observation and experiment) to the knowledge generalising that experience in the form of a theory. So, distinguished sub-disciplines form levels (hence the name: vertical classification) on which the experience performs completely different and characteristically defined functions.

However, this structure requires several comments that lead to the postulate to holistically treat different meanings of the experience category in pedagogy, and - at the same time - to the problem of integrity of pedagogical knowledge.

Firstly, the name empirical pedagogy used on the first level of the structure does not mean that the other sub-disciplines of pedagogy are non-empirical. Pedagogues and authors analysing pedagogical knowledge interpret the term empirical pedagogy in two ways. In its first meaning (used in the structure above), it points to the area of knowledge achieved through the characteristic way of cognition of educational reality which resulted from the evolution of pedagogical research methods associated with the observation and collec-

${ }^{8}$ Kunowski, Podstawy, 38; Marian Nowak, „Podstawy pedagogiki jako ogólna personalistyczna teoria rzeczywistości wychowania", in: Pedagogika ogólna a filozofia nauki. Wybrane problemy poznawcze i konteksty dydaktyczne, ed. Andrzej Pluta (Częstochowa: Wydawnictwo WSP w Częstochowie, 1997), 44; Nowak, Podstawy pedagogiki otwartej, 96-97; Marian Nowak, „Treści i źródła badań pedagogicznych”, in: Metodologiczne problemy tworzenia wiedzy w pedagogice, eds. Jacek Piekarski, Danuta Urbaniak-Zając, Krzysztof J. Szmidt (Kraków: PTP, Oficyna Wydawnicza „Impuls”, 2010), 38; Marian Nowak, „O specyfice podejścia pedagogiki ogólnej do problemów praktyki i teorii pedagogicznej”, in: Pedagogika ogólna. Dyskursy o statusie naukowym i dydaktycznym, ed. Teresa Hejnicka-Bezwińska (Bydgoszcz: Wydawnictwo UKW, 2011), 270; Wolfgang Brezinka, „Empirische Erziehungswissenschaft”, in: Lexikon der Pädagogik, vol. 1, ed. Heinrich Rombach (Freiburg-Basel-Wien: Herder, 1970), 347-348. 
tion of the experience of the subjects of the educational relationship. This definition of empirical pedagogy was noted by S. Kunowski and numerous contemporary authors ${ }^{9}$. The second meaning of the term empirical pedagogy refers to the entire pedagogy as a science which is empirical in nature as it derives its preconditions from specific experiences. For it is not a formal science that would apply a priori premises ${ }^{10}$. The justification for the definition of pedagogy as a whole as an empirical science may also be found in S. Kunowski as, according to the author, even the most important theoretical sub-discipline of pedagogy derives data from empirical and experimental material.

Secondly, the term experimental pedagogy shown in the structure also requires some comment. The name was sometimes replaced with empirical pedagogy. This permitted Ernst Meumann (1862-1915) to state that "experimental pedagogy [...] is both an empirical and an experimental science of the child"11. Władysław Zaczyński noted the erroneous identification of

9 Kunowski, Podstawy, 38; Roman Schulz, „Związek teorii pedagogicznej z praktyką oświatową”, Edukacja. Studia. Badania. Innowacje 4 (1985): 41; Irena Wojnar, „Pedagogika ogólna w świecie (wybrane problemy)”, in: Pedagogika ogólna. Tradycja - teraźniejszość nowe wyzwania, ed. Teresa Hejnicka-Bezwińska (Bydgoszcz: Wydawnictwo Uczelniane WSP w Bydgoszczy, 1995), 97; Stanisław Palka, Metodologia. Badania. Praktyka pedagogiczna (Gdańsk: Gdańskie Wydawnictwo Psychologiczne, 2006), 38-68; Andrzej Bronk, „Pedagogika i filozofia: uwagi metafilozoficzne”, in: Filozofia a pedagogika. Studia i szkice, eds. Piotr Dehnel, Piotr Gutowski (Wrocław: Wydawnictwo Naukowe Dolnośląskiej Szkoły Wyższej Edukacji TWP we Wrocławiu, 2005), 11-12.

${ }^{10}$ Cf. Hejnicka-Bezwińska, W poszukiwaniu, 171-176; Eugeniusz Piotrowski, „Problem wyjaśniania naukowego w pedagogice”, in: Możliwości rozwijania $i$ wykorzystywania teoretycznej wiedzy pedagogicznej. Materiały z międzynarodowej konferencji naukowej zorganizowanej w Uniwersytecie Jagiellońskim w dniach 8 i 9 listopada 1994 roku, ed. Stanisław Palka (Kraków: Uniwersytet Jagielloński, 1995), 49; Bogusława Matwijów, „Strategie badawcze i typy badań pedagogicznych", in: Teoretyczne podstawy pedagogiki, ed. Stanisław Palka (Kraków: Uniwersytet Jagielloński, 1987), 75; Danuta Skulicz, „Innowacyjny aspekt badań pedagogicznych", in: Teoretyczne podstawy pedagogiki, ed. Stanisław Palka, 143; Stanisława Szkotnicka-Lachowicz, „Badania pedagogiczne a praktyka pedagogiczna”, in: Teoretyczne podstawy pedagogiki, ed. Stanisław Palka (Kraków: Uniwersytet Jagielloński, 1987), 149-150; Kazimierz Żegnałek, Metody i techniki stosowane w badaniach pedagogicznych (Warszawa: Wydawnictwo WSP TWP, 2008), 45; Paweł Szmitkowski, „Jednolitość metodologii badań nauk społecznych a wieloznaczność aparatu pojęciowego jej dyscyplin”, in: Badanie - dojrzewanie - rozwój (na drodze do doktoratu). Metodologia nauk społecznych a metodologia badań pedagogicznych, ed. Franciszek Szlosek (Warszawa-Radom: Instytut Pedagogiki Akademii Pedagogiki Specjalnej im. M. Grzegorzewskiej w Warszawie, Instytut Technologii Eksploatacji - PIB w Radomiu, 2016), 119-120.

${ }^{11}$ Ernst Meumann, Zarys pedagogiki eksperymentalnej (Brześć nad Bugiem: Wydawnictwo „Kresów Ilustrowanych”, 1929), 43. 
experimental studies as empirical studies and, consequently, experimental pedagogy as empirical pedagogy ${ }^{12}$. Interestingly, experiment as the main method of experimental pedagogy was not the only method recognised by the practitioners of this sub-discipline. Non-experimental methods of experimental pedagogy mentioned by E. Meumann included: $1^{\mathrm{o}}$ method involving fantastic translocation to the world of a child; $2^{\circ}$ method involving collection of memories from one's own childhood; $3^{\circ}$ comparative-historical-developmental method; $4^{\circ}$ method involving collection of children's work; $5^{\circ}$ method involving observation of a group and an individual which take the form of: a) survey method; b) diary (daily records) method; c) student records keeping method used at schools, and d) psychographic method ${ }^{13}$. The very emergence of a variety of non-experimental methods in the field of experimental pedagogy makes it possible to conclude that pedagogy should consider experience as a source of knowledge in an integral manner, meaning that the use of experiment only, does not always make it possible to draw conclusions from research that would be of value to pedagogy. Besides, one needs to note that pedagogy applied the term experimental pedagogy in relation to experimental schools and which, in the process of education, implemented innovations that would be subject to research. This application of the term experiment clearly differs from the classical, methodological understanding of it $^{14}$. Therefore, Mieczysław Łobocki postulated that experimental pedagogy distinguish a scientific experiment from an implementation experiment, the purpose of which would be to popularise pedagogical innovations ${ }^{15}$.

12 Władysław Zaczyński, Rozwój metody eksperymentalnej i jej zastosowanie w dydaktyce (Warszawa: Państwowe Wydawnictwo Naukowe, 1967), 11.

${ }_{13}$ Meumann, Zarys, 22-26; cf. Ludwik Jaxa-Bykowski, Zasady pedagogiki doświadczalnej ze szczególnym uwzględnieniem szkoły polskiej. Powszechne wykłady uniwersyteckie wygłoszone we Lwowie w roku 1917 (Lwów-Warszawa: Książnica Polska T-wa Nauczycieli Szkół Wyższych, 1920), 10-21; Kazimierz Sośnicki, Rozwój pedagogiki zachodniej na przełomie XIX i XX wieku (Warszawa: Państwowe Zakłady Wydawnictw Szkolnych, 1967), 149-150.

${ }^{14}$ Cf. Stanisław Dobrowolski, Tadeusz Nowacki, Szkoły eksperymentalne w Polsce 1900-1964 (Warszawa: Instytut Wydawniczy „Nasza Księgarnia”, 1966); Wincenty Okoń, „Aktualne problemy pracy eksperymentalnej w dziedzinie wychowania”, Ruch Pedagogiczny 1 (1960): 6; Wincenty Okoń, „Główne problemy eksperymentu szkolnego”, in: Praca eksperymentalna $w$ szkole, ed. Wincenty Okoń (Warszawa: Państwowe Zakłady Wydawnictw Szkolnych, 1963), 11.

${ }^{15}$ Mieczysław Łobocki, „O badaniach eksperymentalnych w pedagogice”, Ruch Pedagogiczny 4 (1985): 60-61. 
Thirdly, and often contrary to common opinions, normative pedagogy does not necessarily have to distance itself from recognising experience as a source of a pedagogical norm, according to Stefan Wołoszyn, as "a pedagogical normative statement deciding, from the pedagogical perspective, what should be"16. For example, W. Zaczyński, writing about Bogdan Suchodolski's methodological tendencies, incorporated normative pedagogy in the pedagogy of ideals which rejected experience as a way of cognising reality, irrespective of the formal expression of the declared specific goals ${ }^{17}$. Contrary to that, formulating the goals of education does not need to exclude the possibility of their empirical justification and specification ${ }^{18}$. If one assumes that ethical and axiological issues are related ${ }^{19}$ to pedagogy (normative pedagogy in particular), then - referring to a very extensive discourse on the empirical foundations of ethics ${ }^{20}$ - one may easily prove that normative pedagogy may be built on the basis of specific experiences. This belief was expressed by Janusz Gnitecki who, when discussing axiological issues of pedagogy, first presented various metaethical opinions ${ }^{21}$. Amongst the opinions based on experience, one might first mention ethical naturalism, ethical emotivism and intuitionism in the Anglo-Saxon, empirical and phenomenological version. However, the inductive ethics they propose do not ensure a definite explanation of the very fact of obligation, which may also be easily reduced to ethology. Therefore, opinions which consider obligations to be absolutely fundamental and non-reducible facts in a moral experience are much more important ${ }^{22}$.

16 Stefan Wołoszyn, „O uzasadnieniu norm pedagogicznych”, Przeglad Filozoficzny 3-4 (1949): 345.

17 Zaczyński, Rozwój, 109; Bogdan Suchodolski, „Pedagogika ideałów i pedagogika życia", Kwartalnik Pedagogiczny 2 (1957): 17-19.

${ }^{18}$ Marian Nowak, „Od kontestacji do powrotu problematyki aksjologicznej i teleologicznej w pedagogice ogólnej”, in: Pedagogika ogólna. Problemy aksjologiczne, eds. Teresa Kukołowicz, Marian Nowak (Lublin: RW KUL, 1997), 36.

19 Cf. Katarzyna Olbrycht, „Wychowanie a wartości”, in: Pedagogika ogólna. Problemy aksjologiczne, eds. Teresa Kukołowicz, Marian Nowak (Lublin: RW KUL, 1997), 47.

${ }^{20}$ Tadeusz Styczeń, Stanisław Kamiński, „Doświadczalny punkt wyjścia etyki”, in: Tadeusz Styczeń, $W$ drodze do etyki. Wybór esejów z etyki i o etyce (Lublin: RW KUL, 1984), 39-73.

${ }^{21}$ Janusz Gnitecki, „Ontologiczne i aksjologiczne wyzwania współczesnej pedagogiki”, in: Pedagogika ogólna. Problemy aksjologiczne, eds. Teresa Kukołowicz, Marian Nowak (Lublin: RW KUL, 1997), 203-206.

22 Jacques Maritain, Moral Philosophy. An Historical and Critical Survey of the Great Systems (London: Geoffrey Bles, 1964), 431; Karol Wojtyła, „Problem doświadczenia w etyce”, 
Fourthly, when asked about the importance of experience in general pedagogy, one might provide an aggregate answer, i.e. that the role of experience here is the result of the sum of its roles in empirical, experimental and normative pedagogy. Then, the meaning of the whole will not exceed the sum of the meanings of its constituents. However, such an answer would be too superficial and fragmented as it would leave out the specific dynamics of the relationships between the vertical sub-disciplines of pedagogy. Thus, general pedagogy's understanding of the experience category as a source of knowledge needs to feature some surplus of meaning which, as it may be foreseen, will not only indicate the need for an integral approach to the issues related to experience, but it will also confirm the integral nature of pedagogical knowledge.

\section{The concept of generality vs. integration of pedagogical knowledge}

The concept of generality in pedagogy is perceived in different ways. Ewa Rodziewicz identified three directions of contemporary reflection on generality in pedagogy, and she incorporated them in the present category. Generality of pedagogy does not become "a static concept, but it is an ongoing, transforming 'spatiotemporal' category expanding its boundaries" 23 . Owing to that understanding of generality, incorporated in the historical and current development of pedagogical thinking, one may discern the dependence of general pedagogy on experience interpreted as empirically provided space for both educational practice and metatheoretical reflections. As much as "general pedagogy, analysing the existence of doctrines of education, keeps a corresponding distance (from the said doctrines)" ${ }^{\prime 24}$, reflections within its framework are not developed in isolation from the current experience (educational reality and self-consciousness of pedagogues-theorists),

Roczniki Filozoficzne 2 (1969): 5-24; cf. Tadeusz Styczeń, „Doświadczenie człowieka i świadczenie człowiekowi (Kardynał Karol Wojtyła jako filozof-moralista)", Znak 3 (1980): 263-274; Andrzej Szostek, „Doświadczenie człowieka i moralności w ujęciu kardynała Karola Wojtyły”, Znak 3 (1980): 275-289.

${ }^{23}$ Ewa Rodziewicz, „Na tropach «ogólności» pedagogicznych. Zamiast wprowadzenia”, Kwartalnik Pedagogiczny 4 (2005): 5.

${ }^{24}$ Marian Nowak, Pedagogiczny profil nauk o wychowaniu. Studium z odniesieniami do pedagogiki pielegniarstwa (Lublin: Wydawnictwo KUL, 2012), 192. 
but they reveal their dependence on the current facts of social and scientific nature. The foregoing thesis is supported by the statements by Teresa Hejnicka-Bezwińska ${ }^{25}$, Bogusław Śliwierski ${ }^{26}$, Ewa Rodziewicz ${ }^{27}$, or Marian Nowak $^{28}$, claiming that the generality category along with general pedagogy has always gained special importance in particular historical situations. This thesis is also, and in particular, supported by the postulates demanding that we should allow for experiences of a considerable social scale, the subjects of which are the developers of educational programs. According to Joanna Rutkowiak, social experiences of the authors of the so-called Small Stories, that appear alongside the currently topical Great Narratives, may be considered the subject matter of general pedagogy, the purpose of which would be to provide inter- and intra-narrative interpretations ${ }^{29}$.

The postulate to link everyday life experience areas with what is the general (equating generality with holiness or celebration) has also been presented by Rafał Godon. The author wrote that the

attempts to separate everyday life from what justifies it, particularise its meaning $[\ldots]$, they condemn it to the continually random and free choices made by a completely unrestrained individual [...]. After all, pedagogues may participate in both the study of the educational aspects of our world and, just like philosophers, in protecting the integrity of the human way of being in the world ${ }^{30}$.

A similar difficulty associated with the autonomisation of everyday life in the methodological approach was described by Jacek Piekarski who, in turn, referred to the opinion of Lech Witkowski. Everyday life, which is only the obviousness of certain types of practice, may be a source of various restrains and restrictions in the critical and rational attitude to the rules of knowledge creation ${ }^{31}$.

${ }^{25}$ Hejnicka-Bezwińska, W poszukiwaniu, 136-162.

${ }^{26}$ Bogusław Śliwerski, Wspótczesne teorie i nurty wychowania (Kraków: Oficyna Wydawnicza „Impuls”, 2004), 10.

27 Rodziewicz, „Na tropach”, 7.

28 Nowak, Pedagogiczny profil, 193-194.

29 Joanna Rutkowiak, „Ogólność pedagogiki a problem przekładu (wobec zwątpienia w tezę o «upadku Wielkich Narracji»)”, Kwartalnik Pedagogiczny 4 (2005): 34-35.

${ }^{30}$ Rafał Godoń, „Pedagogika a niezrozumiałość tego, co ogólne”, Kwartalnik Pedagogiczny 4 (2005): 62.

31 Jacek Piekarski, „Kryteria waloryzacji praktyki badawczej - między inhibicją metodologiczną a permisywnym tolerantyzmem", in: Metodologiczne problemy tworzenia wiedzy 
This statement permitted R. Godon to draw the same conclusion as the one in the previous deliberations when the conclusion was formulated with respect to the experience category. In the author's opinion, one may not deny that generality features some surplus of meaning that cannot be explained by simply summing up what is detailed. Generality incorporates some mystery, some incomprehensibility, which is but a prerequisite for the possibility of experiencing what is general ${ }^{32}$.

On the other hand, however, "generality cannot [...] be captured beyond the experience of what is detailed" ${ }^{33}$. Referring to the statements of HansGeorg Gadamer who, in turn, referred to the writings of Aristotle, R. Godon stated that "the primacy of generality over the detailed, distorts the image of what the actual human experience is because it leaves out the negative nature of experience" 34 .

As R. Godon wrote to supplement his reflections with an interpretation of Plato's works, the negative nature of human experience manifests itself in the setting up of a horizon to what is unclear. Human experience is always accompanied by the "perpetual motion of wondering, remembering, forgetting and recollecting" 35 .

In the light of the above deliberations, pedagogy is to link what is to be described, i.e. the experience of everyday life, and the not-fully-comprehensible ways of updating those experiences that manifest themselves as something new, something mysterious, something demanding generality (celebration).

In pedagogy, none of us have any power over what we are trying to understand. Being an authority in pedagogy does not arise from the knowledge of the rules of education, or the laws that characterise human life. Being a pedagogue requires openness to experiences that render us sensitive to what is important and enable us to get close to the mystery of what is general. Serious pedagogy means "general" pedagogy; it means pedagogy which does not hesitate to ask

w pedagogice, eds. Jacek Piekarski, Danuta Urbaniak-Zając, Krzysztof J. Szmidt (Kraków: PTP, Oficyna Wydawnicza „Impuls”, 2010), 152.
32 Godoń, „Pedagogika”, 67.
${ }^{33}$ Ibidem, 66.
${ }^{34}$ Ibidem, 66-67.
35 Ibidem, 70. 
about what is incomprehensible, and which treats that incomprehensibility with care and respect ${ }^{36}$.

In this sense, pedagogy should not be interpreted as the knowledge of education but as the reflection on education, which is a social being - a reflection that exceeds the experience of the social world, seeing education as a task ${ }^{37}$.

The postulate to treat general pedagogy as a kind of reflection on education, derived from an analysis of the understanding of the generality category, is inclusive of a call for an integral reflection on reality. The experience of everyday life would be incorporated in the not-fully-comprehensible but as real area of mystery (generality). On the other hand, realisation of the existence of this sphere of educational reality which has not been fully comprehended and investigated might affect the respectful attitude towards everyday life experiences of the actors in the educational relationship.

\section{General pedagogy vs. integral pedagogy}

Reflections on the empirical foundations of pedagogical knowledge made it possible to conclude that the vertically distinguished sub-disciplines of pedagogy should interpret experience in an integral manner (which could particularly be seen in the case of experimental pedagogy, which does not only use experiment, but also non-experimental forms of experience). Moreover, the importance of the concept of experience in general (theoretical) pedagogy cannot be the ordinary sum of the meanings of this category, deriving from the other sub-disciplines of pedagogy. General pedagogy, alongside detailed experiences, has its own experiences which manifest themselves in the reflection on the relationships between what is general and what is detailed.

Similarly, deliberations on generality indicated a need for the surplus of meaning of this category and, similarly again, they resulted in specific conclusions related to the understanding of the new tasks of general (theoretical) pedagogy in a new light. This kind of pedagogy, as a field of knowledge re-

36 Ibidem, 71.

37 Andrzej M. Tchorzewski, „Pedagogika ogólna czy metapedagogika”, in: Pedagogika ogólna. Tradycja - teraźniejszość - nowe wyzwania, ed. Teresa Hejnicka-Bezwińska (Bydgoszcz: Wydawnictwo Uczelniane WSP w Bydgoszczy, 1995), 153. 
ferred to as the reflection on education, should allow for both generality and experience in an integral manner.

Conclusions from the deliberations on experience and generality regarding the issues of general pedagogy suggest that this form of pedagogy does not only integrate pedagogical knowledge based on its main categories, but it may be considered as integral pedagogy itself.

Zygmunt Wiatrowski perceived general pedagogy as "an output discipline in the complex of pedagogical sciences [which] needs to affect all the other pedagogical disciplines" ${ }^{38}$. In addition, as Stanisław Palka wrote, in the situation of development of pedagogy, featuring symptoms of disorder, chaos and differentiation, there is a need to focus on the constant points of support, on the constant elements of development, which would be a special task of general pedagogy ${ }^{39}$.

According to M. Nowak, its task is to focus the entire research on what is pedagogical. The task is not so much about the intellectual mastery of reality to better manage it and technically use it, but about its rational study and search for the ultimate meaning ${ }^{40}$.

Thus, general pedagogy may neither be brought down to ideology nor may it be considered an empirical and logical science. Preserving the relationship between them, it is "a place of some peculiar dialectics between ideology, theory and practice, between humanities, natural, social and philosophical sciences, and science in general"41. Therefore, general pedagogy is sometimes perceived not as a separate sub-discipline of pedagogy but as "a mental structure relating in a specific way to the entire pedagogy in general, and to its foundations in particular" ${ }^{\prime 2}$.

38 Zygmunt Wiatrowski, „Miejsce pedagogiki ogólnej w kompleksie nauk pedagogicznych”, in: Pedagogika ogólna. Tradycja - teraźniejszość - nowe wyzwania, ed. Teresa Hejnicka-Bezwińska (Bydgoszcz: Wydawnictwo Uczelniane WSP w Bydgoszczy, 1995), 59.

${ }^{39}$ Stanisław Palka, ,Aktualne sposoby uprawiania pedagogiki ogólnej w Polsce”, in: $\mathrm{Pe}$ dagogika ogólna. Tradycja - teraźniejszość - nowe wyzwania, ed. Teresa Hejnicka-Bezwińska (Bydgoszcz: Wydawnictwo Uczelniane WSP w Bydgoszczy, 1995), 11.

40 Nowak, Pedagogiczny profil, 189-192.

${ }^{41}$ Ibidem, 191.

${ }^{42}$ Andrzej Pluta, „Pedagogika ogólna przez małe «o». Między modernizmem a postmodernizmem", in: Pedagogika ogólna a filozofia nauki. Wybrane problemy poznawcze i konteksty dydaktyczne, ed. Andrzej Pluta (Częstochowa: Wydawnictwo Wyższej Szkoły Pedagogicznej w Częstochowie, 1997), 81; Andrzej Pluta, „Inspiracje ogólnej nauki o pedagogii dla konstrukcji pogranicznych wersji pedagogiki ogólnej”, in: Rozwój pedagogiki ogólnej. Inspiracje i ograniczenia kulturowe oraz poznawcze, ed. Andrzej Bogaj (Warszawa-Kielce: Akademia 
These dialectics are supposed to provide general pedagogy with its generality. It would be based on the fact that

'general pedagogy' (general science of education) should serve all pedagogical sub-disciplines as the most general of their theories [...], but - on the other hand - it should also be as closely linked to detailed pedagogical studies as possible, and it should be able to synthesise and apply their important accomplishments to that general pedagogical mental and cognitive structure... ${ }^{43}$.

Perhaps that is why Irena Wojnar directly recognised general pedagogy as integral pedagogy ${ }^{44}$.

Deliberations regarding the empirical foundations of pedagogical knowledge and understanding of generality have clearly shown that general pedagogy provides a reference point to the other sub-disciplines which, according to the above-mentioned dialectics, affect general pedagogy through their studies covering empirical data. The postulate to treat general pedagogy as reflection on education, or as a mental structure, clearly shows that the tasks of this sub-discipline of pedagogy include integration of the entire pedagogical knowledge. According to the foregoing deliberations, fulfilment of that task may valourise general pedagogues' scientific activity, as recognition of the fact that in the experienced research reality there are incomprehensible elements that demand generality (celebration), building the pedagogue's authority.

\section{References}

Brezinka, Wolfgang. „Empirische Erziehungswissenschaft”. In: Lexikon der Pädagogik, vol. 1, ed. Heinrich Rombach, 347-350. Freiburg-Basel-Wien: Herder, 1970.

Świętokrzyska im. J. Kochanowskiego w Kielcach - Wydawnictwo Instytutu Badań Edukacyjnych w Warszawie, 2001), 151-152.

${ }^{43}$ Stefan Wołoszyn, „Pedagogika ogólna czy system nauk pedagogicznych? Mechanizmy dyferencjacji i reintegracji”, in: Pedagogika ogólna. Tradycja-teraźniejszość - nowe wyzwania, ed. Teresa Hejnicka-Bezwińska (Bydgoszcz: Wydawnictwo Uczelniane WSP w Bydgoszczy, 1995), 54

${ }^{44}$ Irena Wojnar, „Jedność i różnorodność pedagogiki zwanej ogólną”, in: Rozwój pedagogiki ogólnej, ed. Andrzej Bogaj (Warszawa-Kielce: Akademia Świętokrzyska im. J. Kochanowskiego w Kielcach - Wydawnictwo Instytutu Badań Edukacyjnych w Warszawie, 2001), 41-42. 
Bronk, Andrzej. „Pedagogika i filozofia: uwagi metafilozoficzne”. In: Filozofia a pedagogika. Studia i szkice, eds. Piotr Dehnel, Piotr Gutowski, 9-27. Wrocław: Wydawnictwo Naukowe Dolnośląskiej Szkoły Wyższej Edukacji TWP we Wrocławiu, 2005.

Dobrowolski, Stanisław, Tadeusz Nowacki. Szkoły eksperymentalne w Polsce 1900-1964. Warszawa: Instytut Wydawniczy „Nasza Księgarnia”, 1966.

Gnitecki, Janusz. „Ontologiczne i aksjologiczne wyzwania współczesnej pedagogiki”. In: Pedagogika ogólna. Problemy aksjologiczne, eds. Teresa Kukołowicz, Marian Nowak, 197-218. Lublin: RW KUL, 1997.

Godoń, Rafał. „Pedagogika a niezrozumiałość tego, co ogólne”. Kwartalnik Pedagogiczny 4 (2005): 61-72.

Hajduk, Zygmunt. Ogólna metodologia nauk. Lublin: Wydawnictwo KUL, 2005.

Hejnicka-Bezwińska, Teresa. W poszukiwaniu tożsamości pedagogiki. Świadomość teoretyczno-metodologiczna współczesnej pedagogiki polskiej (geneza i stan). Bydgoszcz: Wydawnictwo Uczelniane WSP w Bydgoszczy, 1989.

Jaxa-Bykowski, Ludwik. Zasady pedagogiki doświadczalnej ze szczególnym uwzględnieniem szkoty polskiej. Powszechne wykłady uniwersyteckie wygłoszone we Lwowie w roku 1917. Lwów-Warszawa: Książnica Polska T-wa Nauczycieli Szkół Wyższych, 1920.

Kunowski, Stefan. Podstawy współczesnej pedagogiki. Warszawa: Wydawnictwo Salezjańskie, 2000.

Łobocki, Mieczysław. „O badaniach eksperymentalnych w pedagogice”. Ruch Pedagogiczny 4 (1985): 59-69.

Maritain, Jacques. Moral Philosophy. An Historical and Critical Survey of the Great Systems. London: Geoffrey Bles, 1964.

Matwijów, Bogusława. „Strategie badawcze i typy badań pedagogicznych”. In: Teoretyczne podstawy pedagogiki, ed. Stanisław Palka, 75-84. Kraków: Uniwersytet Jagielloński, 1987.

Meumann, Ernst. Zarys pedagogiki eksperymentalnej. Brześć nad Bugiem: Wydawnictwo „Kresów Ilustrowanych”, 1929.

Nowak, Marian. „O specyfice podejścia pedagogiki ogólnej do problemów praktyki i teorii pedagogicznej”. In: Pedagogika ogólna. Dyskursy o statusie naukowym i dydaktycznym, ed. Teresa Hejnicka-Bezwińska, 265-289. Bydgoszcz: Wydawnictwo UKW, 2011.

Nowak, Marian. „Od kontestacji do powrotu problematyki aksjologicznej i teleologicznej w pedagogice ogólnej”. In: Pedagogika ogólna. Problemy aksjologiczne, eds. Teresa Kukołowicz, Marian Nowak, 33-43. Lublin: RW KUL, 1997.

Nowak, Marian. „Od tradycji pedagogiki ogólnej ku nowym wyzwaniom dla badań nad podstawami edukacji”. In: Pedagogika ogólna. Tradycja-teraźniejszość- 
nowe wyzwania (materiały pokonferencyjne), ed. Teresa Hejnicka-Bezwińska, 107-126. Bydgoszcz: Wydawnictwo Uczelniane WSP w Bydgoszczy, 1995.

Nowak, Marian. Pedagogiczny profil nauk o wychowaniu. Studium z odniesieniami do pedagogiki pielegniarstwa. Lublin: Wydawnictwo KUL, 2012.

Nowak, Marian. „Podstawy pedagogiki jako ogólna personalistyczna teoria rzeczywistości wychowania". In: Pedagogika ogólna a filozofia nauki. Wybrane problemy poznawcze i konteksty dydaktyczne, ed. Andrzej Pluta, 37-59. Częstochowa: Wydawnictwo WSP w Częstochowie, 1997.

Nowak, Marian. Podstawy pedagogiki otwartej. Ujęcie dynamiczne w inspiracji chrześcijańskiej. Lublin: RW KUL, 2000.

Nowak, Marian. „Treści i źródła badań pedagogicznych”. In: Metodologiczne problemy tworzenia wiedzy w pedagogice. Oblicza akademickiej praktyki, eds. Jacek Piekarski, Danuta Urbaniak-Zając, Krzysztof J. Szmidt, 27-39. Kraków: PTP, Oficyna Wydawnicza „Impuls”, 2010.

Okoń, Wincenty. „Aktualne problemy pracy eksperymentalnej w dziedzinie wychowania”. Ruch Pedagogiczny 1 (1960): 4-16.

Okoń, Wincenty. „Główne problemy eksperymentu szkolnego”. In: Praca eksperymentalna w szkole, red. Wincenty Okoń, 5-31. Warszawa: Państwowe Zakłady Wydawnictw Szkolnych, 1963.

Olbrycht, Katarzyna. „Wychowanie a wartości”. In: Pedagogika ogólna. Problemy aksjologiczne, eds. Teresa Kukołowicz, Marian Nowak, 45-51. Lublin: RW KUL, 1997.

Palka, Stanisław. „Aktualne sposoby uprawiania pedagogiki ogólnej w Polsce”. In: Pedagogika ogólna. Tradycja - teraźniejszość - nowe wyzwania (materiaty pokonferencyjne), ed. Teresa Hejnicka-Bezwińska, 9-20. Bydgoszcz: Wydawnictwo Uczelniane WSP w Bydgoszczy, 1995.

Palka, Stanisław. Metodologia. Badania. Praktyka pedagogiczna. Gdańsk: Gdańskie Wydawnictwo Psychologiczne, 2006.

Palka, Stanisław. „Wiedza w pedagogice i wiedza pedagogiczna”. In: Metodologiczne problemy tworzenia wiedzy w pedagogice. Oblicza akademickiej praktyki, eds. Jacek Piekarski, Danuta Urbaniak-Zając, Krzysztof J. Szmidt, 15-25. Kraków: Polskie Towarzystwo Pedagogiczne, Oficyna Wydawnicza „Impuls”, 2010.

Piekarski, Jacek. „Kryteria waloryzacji praktyki badawczej - między inhibicją metodologiczną a permisywnym tolerantyzmem". In: Metodologiczne problemy tworzenia wiedzy w pedagogice. Oblicza akademickiej praktyki, eds. Jacek Piekarski, Danuta Urbaniak-Zając, Krzysztof J. Szmidt, 151-173. Kraków: PTP, Oficyna Wydawnicza „Impuls”, 2010.

Piotrowski, Eugeniusz. „Problem wyjaśniania naukowego w pedagogice”. In: Możliwości rozwijania i wykorzystywania teoretycznej wiedzy pedagogicznej. Мa- 
teriaty z międzynarodowej konferencji naukowej zorganizowanej w Uniwersytecie Jagiellońskim w dniach 8 i 9 listopada 1994 roku, ed. Stanisław Palka, 47-53. Kraków: Uniwersytet Jagielloński, 1995.

Pluta, Andrzej. „Inspiracje ogólnej nauki o pedagogii dla konstrukcji pogranicznych wersji pedagogiki ogólnej”. In: Rozwój pedagogiki ogólnej. Inspiracje i ograniczenia kulturowe oraz poznawcze, ed. Andrzej Bogaj, 147-162. Warszawa-Kielce: Akademia Świętokrzyska im. J. Kochanowskiego w Kielcach - Wydawnictwo Instytutu Badań Edukacyjnych w Warszawie, 2001.

Pluta, Andrzej. „Pedagogika ogólna przez małe «o». Między modernizmem a postmodernizmem". In: Pedagogika ogólna a filozofia nauki. Wybrane problemy poznawcze i konteksty dydaktyczne, red. Andrzej Pluta, 81-93. Częstochowa: Wydawnictwo Wyższej Szkoły Pedagogicznej w Częstochowie, 1997.

Rodziewicz, Ewa. „Na tropach «ogólności» pedagogicznych. Zamiast wprowadzenia”. Kwartalnik Pedagogiczny 4 (2005): 5-27.

Rutkowiak, Joanna. „Ogólność pedagogiki a problem przekładu (wobec zwątpienia w tezę o «upadku Wielkich Narracji»)". Kwartalnik Pedagogiczny 4 (2005): 29-43.

Schulz, Roman. „Związek teorii pedagogicznej z praktyką oświatową”. Edukacja. Studia. Badania. Innowacje 4 (1985): 32-46.

Skulicz, Danuta. „Innowacyjny aspekt badań pedagogicznych”. In: Teoretyczne podstawy pedagogiki, ed. Stanisław Palka, 143-148. Kraków: Uniwersytet Jagielloński, 1987.

Sokołowski, Wojciech. „Empiryzm”. In: Powszechna Encyklopedia Filozofii, vol. 3, ed. Andrzej Maryniarczyk, 142-147. Lublin: Polskie Towarzystwo Tomasza z Akwinu, 2002.

Sośnicki, Kazimierz. Rozwój pedagogiki zachodniej na przełomie XIX i XX wieku. Warszawa: Państwowe Zakłady Wydawnictw Szkolnych, 1967.

Stępień, Antoni B. „Rodzaje bezpośredniego poznania”. Roczniki Filozoficzne 1 (1971): 95-127.

Stępień, Antoni B. „Rola doświadczenia w punkcie wyjścia metafizyki”. Zeszyty Naukowe KUL 4 (1974): 29-37.

Stępień, Antoni B. Wstęp do filozofii. Lublin: Towarzystwo Naukowe Katolickiego Uniwersytetu Lubelskiego, 2001.

Styczeń, Tadeusz. „Doświadczenie człowieka i świadczenie człowiekowi (Kardynał Karol Wojtyła jako filozof-moralista)". Znak 3 (1980): 263-274.

Styczeń, Tadeusz, Stanisław Kamiński. „Doświadczalny punkt wyjścia etyki”. In: Tadeusz Styczeń, W drodze do etyki. Wybór esejów z etyki $i$ o etyce, 39-73. Lublin: Redakcja Wydawnictw KUL, 1984. 
Suchodolski, Bogdan. „Pedagogika ideałów i pedagogika życia”. Kwartalnik Pedagogiczny 2 (1957): 3-40.

Szkotnicka-Lachowicz, Stanisława. „Badania pedagogiczne a praktyka pedagogiczna”. In: Teoretyczne podstawy pedagogiki, ed. Stanisław Palka, 149-156. Kraków: Uniwersytet Jagielloński, 1987.

Szmitkowski, Paweł. „Jednolitość metodologii badań nauk społecznych a wieloznaczność aparatu pojęciowego jej dyscyplin”. In: Badanie - dojrzewanie rozwój (na drodze do doktoratu). Metodologia nauk społecznych a metodologia badań pedagogicznych, ed. Franciszek Szlosek, 119-127. Warszawa-Radom: Instytut Pedagogiki Akademii Pedagogiki Specjalnej im. M. Grzegorzewskiej w Warszawie, Instytut Technologii Eksploatacji - PIB w Radomiu, 2016.

Szostek, Andrzej. „Doświadczenie człowieka i moralności w ujęciu kardynała Karola Wojtyły”. Znak 3 (1980): 275-289.

Śliwerski, Bogusław. Współczesne teorie i nurty wychowania. Kraków: Oficyna Wydawnicza „Impuls”, 2004.

Tchorzewski, Andrzej M. „Pedagogika ogólna czy metapedagogika”. In: Pedagogika ogólna. Tradycja - teraźniejszość - nowe wyzwania (materiaty pokonferencyjne), ed. Teresa Hejnicka-Bezwińska, 151-158. Bydgoszcz: Wydawnictwo Uczelniane WSP w Bydgoszczy, 1995.

Waga, Leszek. Rola doświadczenia w tworzeniu wiedzy pedagogicznej. Lublin: typescript Katolicki Uniwersytet Lubelski Jana Pawła II, 2016.

Wiatrowski, Zygmunt. „Miejsce pedagogiki ogólnej w kompleksie nauk pedagogicznych”. In: Pedagogika ogólna. Tradycja - teraźniejszość - nowe wyzwania (materiaty pokonferencyjne), ed. Teresa Hejnicka-Bezwińska, 55-61. Bydgoszcz: Wydawnictwo Uczelniane WSP w Bydgoszczy, 1995.

Wojnar, Irena. „Jedność i różnorodność pedagogiki zwanej ogólną”. In: Rozwój pedagogiki ogólnej. Inspiracje i ograniczenia kulturowe oraz poznawcze, ed. Andrzej Bogaj, 39-47. Warszawa-Kielce: Akademia Świętokrzyska im. J. Kochanowskiego w Kielcach - Wydawnictwo Instytutu Badań Edukacyjnych w Warszawie, 2001.

Wojnar, Irena. „Pedagogika ogólna w świecie (wybrane problemy)”. In: Pedagogika ogólna. Tradycja - teraźniejszość - nowe wyzwania (materiały pokonferencyjne), ed. Teresa Hejnicka-Bezwińska, 95-105. Bydgoszcz: Wydawnictwo Uczelniane WSP w Bydgoszczy, 1995.

Wojtyła, Karol. „Problem doświadczenia w etyce”. Roczniki Filozoficzne 2 (1969): $5-24$.

Woleński, Jan. Epistemologia. Poznanie. Prawda. Wiedza. Realizm. Warszawa: Wydawnictwo Naukowe PWN, 2007. 
Wołoszyn, Stefan. „O uzasadnieniu norm pedagogicznych”. Przeglad Filozoficzny 3-4 (1949): 345-362.

Wołoszyn, Stefan. „Pedagogika ogólna czy system nauk pedagogicznych? Mechanizmy dyferencjacji i reintegracji”. In: Pedagogika ogólna. Tradycja-teraźniejszość - nowe wyzwania (materiały pokonferencyjne), ed. Teresa Hejnicka-Bezwińska, 47-54. Bydgoszcz: Wydawnictwo Uczelniane WSP w Bydgoszczy, 1995.

Zaczyński, Władysław. Rozwój metody eksperymentalnej i jej zastosowanie $w$ dydaktyce. Warszawa: Państwowe Wydawnictwo Naukowe, 1967.

Żegnałek, Kazimierz. Metody i techniki stosowane w badaniach pedagogicznych. Warszawa: Wydawnictwo WSP TWP, 2008. 
